\title{
Development and performance analysis of a metallic passive micro-direct methanol fuel cell for portable applications
}

\author{
D.S. Falcão ${ }^{a, *}$, J.P. Pereira ${ }^{a}$, C.M. Rangel ${ }^{b}$, A.M.F.R. Pinto ${ }^{a, *}$ \\ ${ }^{a}$ CEFT, Departamento de Engenharia Química, Faculdade de Engenharia da Universidade do Porto, \\ Rua Dr. Roberto Frias, 4200-465 Porto, Portugal \\ ${ }^{\mathrm{b}}$ LNEG, Laboratório Nacional de Energia e Geologia, Fuel Cells and Hydrogen, Paço do Lumiar, 22, 1649-038 Lisboa, \\ Portugal
}

\section{A R T I C L E I N F O}

Article history:

Received 14 July 2014

Received in revised form

29 November 2014

Accepted 9 January 2015

Available online 3 February 2015

Keywords:

Micro passive DMFC

Experimental studies

Methanol concentration

Cell performance

Low catalyst loading

\begin{abstract}
A B S T R A C T
Due to the growing interest on miniaturization for application on portable devices, the Micro Direct Methanol Fuel Cells (Micro-DMFC) proved to have great benefits. Passive fuel cells have extra advantages leading to less complex and cheaper systems. In the present work, an experimental study on the performance of a passive Micro-DMFC with an active area of $2.25 \mathrm{~cm}^{2}$ working at ambient conditions is described. Several commercially available materials for Membrane Electrode Assembly (MEA) are tested including materials with low platinum content to achieve lower prices. The effect of methanol concentration on the cell performance is evaluated. The performance is compared with the one obtained using an active Micro-DMFC with the same active area. A optimized design is proposed corresponding to a maximum power density, $19.2 \mathrm{~mW} / \mathrm{cm}^{2}$, obtained using a Nafion 117 membrane, $3 \mathrm{mg} / \mathrm{cm}^{2} \mathrm{Pt}-\mathrm{Ru}$ and $0.5 \mathrm{mg} / \mathrm{cm}^{2} \mathrm{Pt}$ as, respectively, anode and cathode catalyst loading, carbon paper as anode gas diffusion layer (GDL) and Sigracet carbon paper with micro porous layer (MPL) as cathode GDL at methanol feed concentration of $3 \mathrm{M}$. This result higher than the optimal power obtained with the active Micro-DMFC clearly demonstrates that membranes with low catalyst content could be used in passive MicroDMFC with success. This is an important result bearing in mind the use of micro-DMFCs in portable applications.

Copyright $\odot$ 2015, Hydrogen Energy Publications, LLC. Published by Elsevier Ltd. All rights
\end{abstract}

reserved.

\section{Introduction}

Fuel cells have been considered a promising power source for transportation and portable electronic devices. Supported by the advantages of the scaling laws, miniaturization promises higher efficiency and performance of power generating devices, and therefore Micro-DMFC is an emergent technology. These cells use liquid fuels without a reforming step and can provide up to ten times the energy density of conventional batteries. Liquid alcohol fuels have high energy density and are easier to transport, store and handle than the hydrogen.

\footnotetext{
* Corresponding authors. Tel.: +35 1225081675; fax: +35 1225081449.

E-mail addresses: dfalcao@fe.up.pt (D.S. Falcão), apinto@fe.up.pt (A.M.F.R. Pinto). http://dx.doi.org/10.1016/j.ijhydene.2015.01.034

0360-3199/Copyright @ 2015, Hydrogen Energy Publications, LLC. Published by Elsevier Ltd. All rights reserved.
} 